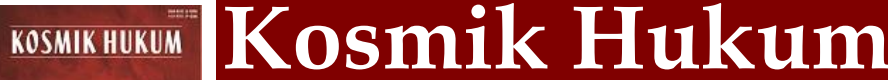

\author{
Fakultas Hukum
}

Universitas Muhammadiyah Purwokerto

Vol. 19 No. 2 (2019)

\section{Optimalisasi Pengawasan Perizinan dan Perpanjangan Trayek Angkutan Kota (Studi di Kabupaten Banjarnegara)}

\author{
Krisna Pramesti Putra ${ }^{凶}$, Indriati Amarini, Ika Ariani Kartini \\ Fakultas Hukum Universitas Muhammadiyah Purwokerto \\ E-mail: krisna.murti22@gmail.com
}

\begin{abstract}
Municipal transportation means of transportation are required to have a route permit and are obliged to extend route permits that have expired. The issuance of route permits and extension of route permits is carried out by the Transportation Agency. This research is a normative juridical research. The data used is secondary data sourced from books, research reports, scientific journals and legislation. Interviews were conducted to add secondary data. The results showed that many city transportation have not extended their route permits. The Banjarnegara Regency Transportation Office as a service provider, carries out supervision, provides guidance / socialization as well as evaluations and reports. The obstacles faced in the supervision are the lack of operational implementation and the attitude of city transport owners who have not routinely extended route permits. Optimization from the Banjarnegara Regency Transportation Office in the form of increased guidance for vehicle owners, coordination with police agencies in law enforcement against violations of route permits. Evaluation is needed in the form of ease of granting route permits and the apparatus' assertiveness against violators of route permits.
\end{abstract}

Keywords: Supervision, Route Permit, City Transportation

\begin{abstract}
Abstrak
Alat transportasi angkutan kota wajib memiliki izin trayek dan wajib memperpanjang izin trayek yang telah habis. Pelaksanaan pemberian izin trayek dan perpanjangan izin trayek dilakukan oleh Dinas Perhubungan. Penelitian ini adalah penelitian yuridis normative. Data yang dipergunakan adalah data sekunder yang bersumber pada buku-buku, laporan penelitian, jurnal ilmiah dan perundangundangan. Wawancara dilakukan untuk menambah data sekunder. Hasil penelitian menunjukkan banyak angkutan kota belum memperpanjang izin trayek. Dinas Perhubungan Kabupaten Banjarnegara sebagai pemberi layanan, melakukan pengawasan, memberikan pembinaan/sosialiasasi serta evaluasi dan laporan. Hambatan yang dihadapi dalam pengawasan adalah minimnya pelaksanaan operasi dan sikap pemilik angkutan kota yang belum rutin memperpanjang izin trayek. Optimalisasi dari Dinas Perhubungan Kabupaten Banjarnegara berupa peningkatan pembinaan terhadap pemilik kendaraan, koordinasi dengan instansi kepolisian dalam penegakan hukum terhadap pelanggaran izin trayek. Perlunya evaluasi berupa kemudahan dalam pemberian izin trayek dan ketegasan dari aparat terhadap pelanggar izin trayek.
\end{abstract}

Kata kunci: Pengawasan, Izin Trayek, Angkutan kota

Copyright@2019KosmikHukum. All rights reserved.

\section{Pendahuluan}

Transportasi sangat dituntut peranannya dalam pembangunan suatu negara. Keberhasilan pembangunan yang telah dicapai di segala bidang, sektor transportasi sangat menentukan. Transportasi bukan hanya untuk melancarkan arus barang dan mobilitas sumbersumber ekonomi secara baik. ${ }^{1}$ Melalui pembangunan jangka panjang peranan transportasi dapat memberi pelayanan yang baik untuk kegiatan manusia. Sektor transportasi harus dilaksanakan secara multidimensional, dimana harus memperhatikan tidak hanya situasi dan

Peraturan Bupati Banjarnegara No 74 Tahun 2016 Tentang Kedudukan, Susunan Organisasi, Tugas Dan Fungsi Serta Tata Kerja Dinas Perhubungan Kabupaten Banjarnegara. 
kondisi transportasi itu sendiri tetapi juga harus dapat memperhatikan lingkungan yang dipengaruhinya dan mempengaruhinya termasuk sarana dan prasarana. Seiring perkembangan kota maka kebutuhan transportasi di perkotaan meningkat pula, sehingga menyebabkan permasalahan transportasi menjadi sangat kompleks sehingga diperlukan tindakan penanganan yang sesegera mungkin. ${ }^{2}$

Dengan meningkatnya kebutuhan angkutan umum oleh masyarakat kota Banjarnegara maka angkutan umum jenis mikrolet semakin bertambah pula seturut kebutuhan akan angkutan umum yang bertambah. Dengan kebutuhan angkutan umum jenis mikro yang bertambah maka masyarakat tertarik bekerja sebagai sopir angkutan umum mikrolet. Berkaitan dengan izin trayek, adanya aktivitas lalu lintas yang cukup tinggi di Kabupaten Banjarnegara tidak menutup kemungkinan terjadinya pelanggaran-pelanggaran. Salah satu yang disorot adalah pelanggaran dalam bidang transportasi yakni perizinan trayek angkutan dan perpanjang trayek. Sebelum mengeluarkan perpanjangan izin trayek kendaraan yang usianya 21 tahun sampai 25 tahun harus disertai dengan uji kir. Tanpa uji kir, maka izin trayek tidak dapat diperpanjang, untuk meningkatkan keselamatan penumpang. ${ }^{3}$

Dinas Perhubungan Kabupaten Banjarnegara melakukan verifikasi angkutan yang melayani perpanjang trayek. Masih banyak mikro jurusan Banjarnegara - Purwokerto tahun pembuatannya dibawah 1992. Bahkan ada satu mikro lansiran tahun 1985, sehingga usianya sudah lebih dari 30 tahun. Mikro jurusan Kondisi serupa juga terjadi pada mikro jurusan Banjarnegara - Karangkobar - Kalibening yang usianya sudah lebih dari 25 tahun. Angkudes jurusan Banjarnegara - Tunggara, paling tua lansiran tahun 1993. Angkutan lainnya lainnya rata-rata keluaran tahun 2.000 atau lebih baru. Penelitian ini bertujuan menganalisis tentang pelaksanaan pengawasan perizinan dan perpanjangan Trayek angkutan kota di Kabupaten Banjarnegara. ${ }^{4}$

\section{Rumusan Masalah}

Berdasarkan latar belakang, ada dua permasalahan yaitu, Pertama; Bagaimana pelaksanaan pengawasan perpanjangan izin trayek Angkutan kota Di Kabupaten Banjarnegara? Kedua, Apa hambatan yang dihadapi Dinas Perhubungan Kabupaten Banjarnegara dalam pengawasan izin dan perpanjangan trayek angkutan kota di Kabupaten Banjarnegara.

\section{Metodologi Penelitian}

Metode penelitian yang digunakan dalam penelitian ini adalah pendekatan Yuridis Normatif yaitu penelitian hukum yang dilakukan dengan pengumpulan data sekunder. Data Sekunder yang digunakan berupa buku, jurnal, hasil penelitian, dokumen dan peraturan perundang-undangan terkait. Wawancara dengan pejabat terkait bersifat menambah data sekunder yang ada. Selanjutnya data-data dianalisis secara normative kualitatif.

\section{Hasil dan Pembahasan}

1. Pelaksanaan Pengawasan Perijinan Perpanjangan Izin Trayek Angkutan kota Di Kabupaten Banjarenegara

Izin trayek adalah dokumen berupa surat keputusan dan akrtu pengawasan. Kedua dokumen tersebut wajib diregistrasi ulang atau diperpanjang apabila angkutan perdesaan yang digunakan masih beroperasi. Hal ini juga berkaitan dengan pendapatan asli daerah. Berkaitan dengan penertiban izin trayek angkutan perdesaan, Dinas Perhubungan Kabupaten Banjarnegara melaksanakan peranannya dalam hal perpanjangan izin trayek angkutan kota dengan jalan : (1) Pelayanan yang cepat dan mudah. Pembinaan dan pengawasan tidak semata-

\footnotetext{
2 Radar Banyumas, "Puluhan Angkutan Banjarnegara Mendesak Diremajakan", Dikutip dari laman: https://radarbanyumas.co.id/puluhan-angkutan-banjarnegara-mendesak-diremajakan/

3 Sutedi, Adrian, Hukum perizinan dalam sektor pelayanan publik. (Sinar Grafika, Jakarta, 2013), hlm. 5

$4 \quad$ Neni Sri Imaniyati, Hukum Bisnis, (Yogjakarta: Graha Ilmu, 2013), Hlm. 255.
} 
mata hanya pada meningkatkan pendapatan asli daerah, namun memprioritaskan pelayanan publik, karena itu juga merupakan hak masyarakat yang sebaliknya menjadi kewajiban pemerintah daerah. ${ }^{5}$

Izin trayek tidak dibayarkan dalam waktu lima tahun sekali guna memberikan kemudahan bagi pemilik angkutan umum kota untuk memenuhi persyaratan administrasi. Apabila kartu pegawasan tersebut tidak diperbaharui maka pemilik angkutan umum kota dikenakan sanksi. Sebab pembaharuan kartu pengawasan berhubungan erat dengan retribusi izin trayek. ${ }^{6}$ Dinas Perhubungan Kabupaten Banjarnegara adalah unsur pelaksana otonomi daerah yang bertanggungjawab kepada Bupati. ${ }^{7}$ Dinas Perhubungan melaksanakan urusan wajib pemerintahan di bidang perhubungan. Salah satunya adalah penerbitan izin trayek. Izin trayek yang dikeluarkan oleh Dinas Perhubungan di wilayah Kabupaten adalah izin trayek angkutan kota. Sebagaimana dalam Undang-undang Nomor 22 Tahun 2009 tentang Lalu Lintas dan Angkutan Jalan Pasal 176 huruf d menyebutkan“ izin penyelenggaraan angkutan orang dalam trayek diberikan oleh Bupati untuk penyelenggaraan angkutan orang yang melayani trayek perdesaan yang berada dalam satu wilayah kabupaten". Salah satu tugas pokok dan fungsi Dinas Perhubungan Kabupaten Banjarnegara tertuang dalam Peraturan Bupati Banjarnegara Nomor 74 Tahun 2016 tentang Organisasi dan Tata Kerja Dinas Perhubungan. Pada pasal 14 Peraturan Bupati Nomor 74 Tahun 2016 menyebutkan seksi angkutan mempunyai tugas melaksanakan penyelenggaraan angkutan orang dan barang.

Pengurusan perpanjangan izin trayek berpedoman pada Keputusan Menteri Nomor 35 Tahun 2003. Pasal 48 mengatur tentang persyaratan administrasi untuk perpanjangan izin trayek. Dengan tetap berpedoman Dinas Perhubungan memberikan syarat-syarat administrasi yang lebih memudahkan pemilik angkutan kota dalam mengurus izin trayek. Persyaratan untuk mengurus perpanjangan izin trayek adalah : (a) Izin usaha angkutan (b) Fotocopy akta pendirian perusahaan dan surat izin usaha perusahaan (SIUP) bagi pemohon yang berbentuk adan usaha, akte pendirian koperasi atau badan hukum lainnya bagi pemohon yang berbentuk koperasi atau PT, KTP bagi pemohon perorangan; Fotocopy NPWP. 8 Setelah mengurus persyaratan diatas, Dinas Perhubungan akan mengeluarkan izin trayek berupa surat keputusan yang berlaku 5 tahun dan kartu pengawasan yang berlaku satu tahun. kartu pengawasan setiap tahun wajib diperpanjang. Syarat memperpanjang kartu pengawasan adalah: Fotocopy STNK; Fotocopy KTP; Fotocoy buku uji kir; Kartu pengawasan yang lama. ${ }^{9}$

Pengawasan merupakan salah satu tahapan penting dari adanya suatu aturan. Adanya suatu pengawasan dapat mengukur sejauh mana aturan tersebut sudah dilaksanakan atau dijalankan oleh suatu dinas. Adanya peraturan yang mengatur, maka Dinas Perhubungan selaku Dinas yang berwenang serta bertanggung jawab terhadap jalannya angkutan kota, maka Dinas Perhubungan juga wajib mengawasi setiap ketentuan atau aturan yang berlaku untuk setiap angkutan angkota yang berada di Kota Banjarnegara apakah sudah berjalan sesuai dengan ketentuan atau belum. ${ }^{10}$

Pengawasan ini merupakan proses dimana aspek tertentu dari suatu prosedur harus disetujui dahulu dalam melaksanakan kegiatan sehingga dapat menetapkan pelaksanaan dan saksi yang diberikan jika terjadi penyimpangan. Sanksi administratif diberikan jika ditemukan Angkutan Kota yang beroperasi tidak dalam kondisi standar fisik yang sudah ditentukan. Sepirti ukuran, bentuk tulisan dan bentuk identitas kendaraan pada angkutan Kota, tetapi Dinas Perhubungan sendiri belum mampu menjalankan pengawasan tersebut terbukti masih banyak nya para sopir angkutan kota mengemudi dengan cara tidak disiplin. Sehingga dengan

Hasil wawancara dengan Staff Dinas Perhubungan bagian Angkutan pada 13 April 2020

Pasal 14 Peraturan Bupati Nomor 74 Tahun 2016 tentang Oganisasidan Tata Kerja Dinas Perhubun

Hasil wawancara dengan Staff Bayu Dinas Perhubungan bagian Angkutan pada 13 April 2020

Peratuan Daerah No 8 tahun 2017 Pasal 81

Fachruddin, I, (2013). Pengawasan Peradilan Administrasi Terhadap Tindakan Pemerintah. Alumni, Bandung, Hlm. 23

10 Abdurahman, A, (2011). Aspek-aspek Pengawasan di Indonesia. Sinar Grafika, Jakarta, Hlm. 40 
begitu dapat dikatakan peraturan belum berjalan maksimal karena pengawasan oleh Dinas Perhubungan Kota Banjarnegara yang belum maksimal. ${ }^{11}$

Pengawasan merupakan salah satu tahapan penting dari adanya suatu aturan. Adanya suatu pengawasan dapat mengukur sejauh mana aturan tersebut sudah dilaksanakan atau dijalankan oleh suatu dinas. Adanya peraturan yang mengatur, maka Dinas berwenang serta bertanggung jawab terhadap jalannya angkutan kota, maka Dinas Perhubungan juga wajib mengawasi setiap ketentuan atau aturan yang berlaku untuk setiap angkutan angkota yang berada di Banjarnegara apakah sudah berjalan sesuai dengan ketentuan atau belum. Dalam melaksanakan fungsi pengawasan, Dinas Perhubungan melakukan pengawasan kegiatan angkutan umum kota melalui kartu pengawasan. Sebagaimana telah disebutkan kartu pengawasan digunakan untuk memudahkan kontrol yang berlaku selama satu tahun terhadap akstivitas angkutan umum Kota. ${ }^{12}$

Hambatan Dinas Perhubungan Kabupaten Banjarnegara dalam Pengawasan Perpanjangan Izin Trayek Angkutan Kota ada dua yaitu Internal dan Eksternal. Hambatan Internal berupa : Pertama, Dinas Perhubungan kesulitan untuk menghubungi pemilik angkutan umum kota ketika diketahui izin trayek kartu pengawasannya telah habis. Sebab, terkadang kalau harus mendatangi/menghubungi satu-persatu pemilik angkutan umum kota dirasa cukup sulit untuk ditindak dan membuang banyak waktu. Kedua, dalam melaksanakan operasi, Dinas Perhubungan Kabupaten Banjarnegara bekerjasama dengan pihak kepolisian. Yang menjadi permasalahan adalah sulitnya menetukan waktu yang tepat untuk mensikronkan kegiatan masing-masing. Sedangkan hambatan eksternal dalam pelaksanaan perpanjangan izin trayek salah satunya adalah sikap tidak peduli oleh pemilik angkutan kota. Salah satu yang menjadi faktor penyebab adalah minimnya penumpang. Hal ini disebabkan semakin banyak munculnya jasa angkutan ojek. Karena itu pemilik angkutan umum perdesaan merasa rugi mengeluarkan biaya untuk retribusi izin trayek sedangkan penghasilan yang didapatkan tidak sebanding.

Tabel 1.1

Data Kendaraan Angkutan yang ada di Kabubapten Banjarnegara Tahun 2018

\begin{tabular}{|c|c|c|c|c|c|}
\hline No & Jaringan Trayek & \multicolumn{4}{|c|}{ Jumlah Armada } \\
\hline & Mikrobus & Bus Besar & Bus Sedang & Bus Kecil & Minibus \\
\hline 1 & $\begin{array}{l}\text { Banjarnegara - Wanadadi - } \\
\text { Punggelan - PP }\end{array}$ & - & & 42 Unit & \\
\hline 2 & Banjarnegara - Pagentan - PP & - & & 23 Unit & \\
\hline 3 & $\begin{array}{l}\text { Banjarnegara - Karangkobar - } \\
\text { Kalibening - PP }\end{array}$ & - & & 70 Unit & \\
\hline 4 & $\begin{array}{l}\text { Banjarnegara - Klampok - } \\
\text { Banyumas - Purwokerto - PP }\end{array}$ & - & & 135 Unit & \\
\hline 5 & $\begin{array}{l}\text { Wonosobo - Banjarnegara - } \\
\text { purbalingga - Purwokerto - PP }\end{array}$ & - & - & & \\
\hline 6 & $\begin{array}{l}\text { Purwokerto - Purbalingga - } \\
\text { Banjarnegara - Wonosobo - } \\
\text { Semarang - PP }\end{array}$ & 1 Unit & 1 Unit & - & \\
\hline & Jumlah & 1 & 1 & 270 & \\
\hline
\end{tabular}

Sumber: Dinas Perhubungan, 2018

Beberapa pelanggaran-pelanggraan yang biasanya dilakukan oleh pemilik angkutan umum Kota adalah: a.) Melakukan kegiatan penarikan penumpang diluar trayek b.) Izin trayek (surat keputusan atau kartu pengawasan) mati atau telah habis masa berlakunya c.)Pembelian mobil angkutan yang tidak dibalik nama d.) Tidak melaporkan penjualan mobil angkutan milik

11 Ratna, S. (2016), Cendekia Jurnal Ilmu Administrasi Negara , Volume IX No. 1 Januari - Juni 2016

12 Jurnal Online Mahasiswa FISIP Vol. 4 No. 2 Oktober 2017 
pribadi. Dari data yang di ambil dari dinas perhubungan masih banyak sekali pelanggaran yang dilakukan oleh pemilik usaha angkutan umum kota.

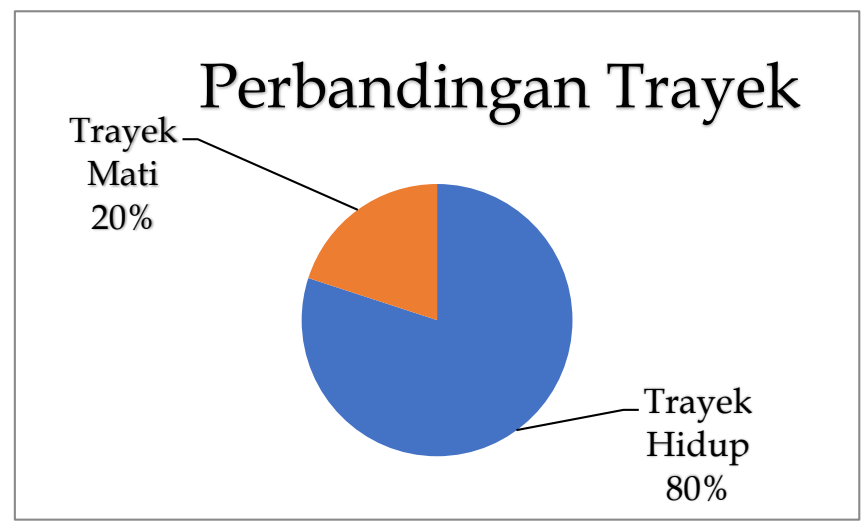

Sumber: Data sekunder, Dinas Perhubungan, 2018, Diolah

Dalam rangka penegakan hukum atas pelanggaran-pelanggaran terhadap izin trayek, Dinas Perhubungan Kabupaten Banjarnegara melakukan proses operasi bekerjasama dengan pihak kepolisian. Operasi dilakukan dalam rangka pemberian efek jera kepada pemilik angkutan umum kota. berikut adalah ketentuan-ketentuan saat operasi di lapangan: sebagai : (a) Pada saat operasi, pemilik angkutan umum Kota supir wajib menunjukkan STNK, SIM, Kartu pengawasan, dan buku uji kir. (b) Apabila ada pelanggaran terhadap surat keputusan, kartu pengawasan dan buku uji kir, yang berwenang menindak adalah Dinas Perhubungan Kabupaten Banjarnegara. (c) Setelah penilangan, semua berkas-berkas yang telah diperoleh diserahkan ke Kordinator Pengawas kemudian dibawa ke kepolisian untuk direkap ulang dan setelah itu oleh pihak kepolisian dibawa ke Pengadilan Negeri untuk diproses/sidang. (d) Pemilik angkutan setelah diproses di Pengadilan Negeri tetap wajib memperpanjang izin trayeknya di Dinas Perhubungan Kabupaten Banjarnegara sesuai dengan retribusi yang wajib dibayarkan. ${ }^{13}$

\section{Optimalisasi Pengawasan Perizinan dan perpanjangan ijin trayek angkutan kota Di kabupaten Banjarnegara}

Dinas Perhubungan Kabupaten Banjarnegara memberikan pelayanan yang cepat dalam pengurusan izin. Pelayanan cepat yang dimaksud adalah pemilik angkutan umum kota yang mengurus izin tidak perlu menunggu lama untuk terbitnya suatu izin. Dinas perhubungan memberikan estimasi waktu selama 30 menit surat izin trayek baik itu berupa surat keputusan atau kartu pengawasan. Dengan adanya pelayanan yang mudah dan cepat ini maka memungkinkan pemilik angkutan untuk memenuhi kewajibannya sebagai pemilik angkutan umum kota agar mematuhi peraturan-peraturan yang telah ada. ${ }^{14}$

Dalam melaksanakan fungsi pengawasan, Dinas Perhubungan melakukan pengawasan kegiatan angkutan umum kota melalui kartu pengawasan. Sebagaimana telah disebutkan kartu pengawasan digunakan untuk memudahkan kontrol yang berlaku selama satu tahun terhadap akstivitas angkutan umum kota, dengan adanya kartu pengawasan Dinas Perhubungan akan mengetahui apakah izin trayek yang diberikan sudah diregistrasi ulang atau belum. Pengawasan juga dilaksanakan dalam rangka penegakan hukum. Penegakan hukum dilakukan oleh Dinas perhubungan dengan menerapkan sanksi-sanksi yang telah ditentukan. ${ }^{15}$

\footnotetext{
Tersedia di website :http:// www.perhubungan.jatengprov.go.id/

Tersedia di website : https://dinhub.banjarnegarakab.go.id/

15 Jurnal Online Mahasiswa FISIP Vol. 4 No. 2 Oktober 2017 Pudyatmoko, Y. Sri, Perizinan Problem dan Upaya Pembenahan, Grasindo, Jakarta, 2009, Hlm.40. Lihat juga pada Tjakranegara, Soegijatna, Hukum Pengangkutan Barang dan Penumpang. Rineka, Jakarta, 2015, Hlm. 80
} 
Dalam pelaksanaan sanksi terhadap pelanggaran izin trayek, Dinas Perhubungan bekerjasama dengan pihak kepolisian. Kerjasama ini diwujudkan dalam bentuk melakukan operasi di jalan raya atau di terminal terhadap angkutan umum. Kegiatan operasi ini menjadi salah satu tugas pokok seksi pengendalian dan operasional. Dari adannya operasi ini dapat diketahui pemilik angkutan umum mana yang melanggar aturan-aturan.

Kegiatan Dinas Perhubungan Banjarnegara adalah Pembinaan/Sosialisasi kepada Pemilik Angkutan Kota. Salah satu pendekatan pembinaan yang digunakan oleh Dinas Perhubungan Kabupaten Banjarnegara adalah dengan memberikan sosialisasi. Sosialisasi diadakan setiap 5 bulan sekali di tempat yang berbeda. Sosialisasi dilakukan terminal-terminal atau ditempat pusat berhentinya angkutan kota. Sosialisasi tidak hanya diberikan kepada pemilik angkutan kota dan supir, melainkan kepada pelajar. Sosialisasi diadakan setiap 3 bulan sekali di tempat yang berbeda. Sosialisasi dilakukan terminal-terminal, di Dinas Perhubungan atau di pendopo. Sosialisasi ini diberikan dalam rangka untuk mensosialisasikan peraturan peraturan yang baru, penyuluhan tentang izin trayek, cara berlalu lintas dengan baik, penerbitan surat peringatan/teguran lisan kepada pemilik angkutan Kota, dan sebagainya yang berhubungan dengan lalu lintas dan angkutan jalan. Pelaksanaan pembinaan dapat dilakukan setiap saat dengan melihat situasi dan kondisi yang meungkinkan untuk segera dilakukan pembinaan. Kegiatan pembinaan melibatkan pihak kepolisian sebagai pemberi materi. Dinas Perhubungan sebagai fasilitator dan memanajemen pelaksanaan pembinaan. ${ }^{16}$

Kegiatan yang lain adalah Evaluasi dan Laporan. Evaluasi dan laporan dibuat oleh Dinas Perhubungan Kabupaten Banjarnegara guna sebagai tolak ukur keberhasilan selama beberapa kurun waktu tertentu dalam menjalankan tugas pokok dan fungsinya. Pelaporan dilakukan setiap bulan kepada Kepala Dinas Perhubungan. Laporan yang dibuat berisi tentang beberapa permasalahan yang dihadapi oleh Dinas Perhubungan dari semua bidang beserta penyelesaiannya serta keberhasilan suatu program kegiatan. ${ }^{17}$

Berkaitan dengan salah satu faktor utama penyebab pemilik angkutan tidak memperpanjang izin trayek, yaitu penghasilan yang sedikit, Dinas Perhubungan Kabupaten Banjarnegara melakukan tinjauan tarif retribusi sebagaimana yang disebutkan dalam Pasal 108 ayat 1-3 Peraturan Daerah Kabupaten Banjarnegara Nomor 6 tahun 2011. Disebutkan pada ayat (1) Tarif Retribusi ditinjau kembali paling lama 3 (tiga) tahun sekali. (2) Peninjauan tarif Retribusi sebagaimana dimaksud pada ayat (1) dilakukan dengan memperhatikan indeks harga dan perkembangan perekonomian. (3) Penetapan tarif Retribusi sebagaimana dimaksud pada ayat (2) ditetapkan dengan Peraturan Bupati. ${ }^{18}$

Upaya Dinas Perhubungan Kabupaten Banjarnegara dalam Menangani Hambatan yang Dihadapi yaitu Pertama : Solusi Untuk Mengatasi Hambatan Internal, Peningkatan Pengawasan dan Pembinaan. Peningkatan pengawasan saat uji kir, dapat mengurangi kesulitan dari pihak Dinas Perhubungan untuk menghubingi pemilik angkutan yang sudah habis masa berlakunya. Pengawasan saat uji kir diberikan melalui peringatan lisan. Pebinaan dilakukan dalam rangka memberikan pernyuluhan terhadap keselamatan penumpang, izin yang harus dipatuhi, dan sebagainya yang berhubungan dengan kewenangan Dinas Perhubungan. Pembinaan ini Dinas Perhubungan juga memeberikan terguran atau peringatan atas perlanggaran yang dilakukan oleh pemilik amgkutan umum kota. Solusi ini adalah dengan mengirimkan surat teguran untuk memperpanjang izin trayek bagi pemilik angkutan umum kota yang tidak memperpanjang izin trayeknya. Kedua: Sinkronisasi jadwal saat awal pembentukan program. Operasi gabungan dilakukan bekerjasama dengan pihak kepolisian untuk menertibkan berbagai pelanggaran-pelanggaran. Tidak hanya pelanggaran pelangaran yang berkaitan dengan izin trayek namun juga pelanggaran pelanggaran terhadap lalu lintas. Adanya penyesuaian jadwal yang terencana dengan pihak kepolisian di awal pembentukan kegiatan menjadi salah satu upaya Dinas Perhubungan Kabupaten Banjarnegara untuk

\footnotetext{
Pudyatmoko, Y. Sri, Perizinan Problem dan Upaya Pembenahan, Grasindo, Jakarta, 2009, Hlm. 40

Tjakranegara, Soegijatna, Hukum Pengangkutan Barang dan Penumpang. Rineka, Jakarta, 2015, Hlm. 80

Peraturan Daerah Kabupaten Banjarnegara Nomor 6 tahun 2011
} 
menjalin kerjasama yang baik. Apabila di lapangan ditemukan suatu kendala maka Dinas Perhubungan tetap berupaya untuk melakukan operasi sebagaimana kondisi semestinya dalam rangka penegakan hukum.

Adapun Solusi Untuk Mengatasi Hambatan Eksternal yaitu Keberadaan ojek yang dianggap sebagai salah satu faktor pelanggaran terhadap pengurusan izin trayek perlu mendapat perhatian baru. Pemilik angkutan umum merasa rugi ketika harus mengurus izin sedangkan pendapatan yang diterima sedikit atau berkurang, sebab keberadaan ojek mulai bertambah di terminal-terminal. Ojek-ojek yang sudah resmi adalah binaan Polres, yang menjadi perhatian adalah adanya ojek-ojek liar yang juga menarik penumpang di terminalterminal. Dalam rangka mengayomi pemilik angkutan kota maka sosialisasi terhadap ojek online perlu dilakukan. ${ }^{19}$ Salah satu usulan dari pemilik angkutan adalah adanya penertiban kembali keberadaan ojek online. Penertiban ini dilakukan dengan cara memberikan tempat tersendiri beroperasinya. Guna menunjang terlaksananya suatu aturan maka Dinas Perhubungan memberikan ketegasan kepada pemilik angkutan umum agar dengan kondisi apapun untuk tetap memenuhi persyaratan yang ada. Ketegasan ini dilakukan dengan tidak pandang bulu terhadap penegakan hukum.

\section{Penutup}

\section{Kesimpulan}

Pengawasan Dinas Perhubungan Kabupaten Banjarnegara dalam pelaksanaan perpanjangan izin trayek angkutan kota berdasarkan Peraturan Daerah Kabupaten Banjarnegara Nomor 6 Tahun 2011. Pelayanan yang diberikan dilakukan dengan cepat dan mudah. Disamping pelayanan, Dinas Perhubungan juga melakukan pengawasan. Pengawasan yang dilakukan oleh Dinas Perhubungan adalah saat uji kir dan pengawasan di lapangan yang bekerjasama dengan kepolisian. Dinas Perhubungan juga memberikan pembinaan dan sosialisasi kepada pemilik angkutan kota setiap tiga bulan sekali. Selain itu Dinas Perhubungan melakukan evaluasi dan laporan yang dilaksanakan setiap bulan sebagai bentuk pertanggungjawaban atas tugas yang dilaksanakan.

Dinas Perhubungan dalam melaksanakanan tugas menghadapi beberapa hambatan. Hambatan-hambatan tersebut berupa hambatan internal dan eksternal. Hambatan internal adalah dalam hal pengawasan yakni sulit menghubungi pemilik angkutan kota mengenai izin trayeknya yang sudah habis, sulit menentukan waktu untuk bekerjasama dengan pihak kepolisian, serta minimnya dana untuk operasi gabungan. Sedangkan hambatan eksternal adalah berkaitan dengan pembinaan/sosialisasi, yaitu sikap tidak peduli pemilik angkutan kota. Oleh karena itu diperlukan optimalisasi Dinas Perhubungan Kabupaten Banjarnegara berupa : Pertama : Peningkatan Pembinaan dan Pengawasan sebagai bentuk solusi untuk mengatasi sulitnya menghubungi pemilik angkutan kota mengenai izin trayek yang sudah habis. Pengawasan dilakukan saat uji kir. Solusi lain adalah pengiriman surat teguran kepada pemilik angkutan yang tidak memperpanjang izin trayek dan Sinkronisasi Jadwal Saat Pembentukan Program sebagai bentuk solusi untuk bekerjasama dengan kepolisian agar dapat terlaksana kegiatan pengawasan di jalan. Kedua : Adanya sikap tidak peduli dari pemilik angkutan umum kota, maka Dinas Perhubungan Kabupaten Banjarnegara bersikap tegas terhadap pemilik angkutan umum kota yang melakukan pelanggaran diantaranya dengan memberikan surat teguran tertulis/lisan agar pemilik angkutan memenuhi ketentuan peraturan yang berlaku.

\section{Saran}

Dinas Perhubungan perlu melakukan evaluasi terhadap kinerja perangkatnya dan program-program kegiatan mulai dari pembinaan hingga pengawasan agar tugas-tugas yang diemban dapat terlaksana dengan maksimal.Perlu ada tinjauan ulang terhadap pelaksanaan

19 Sofi Wahyu Ningrum,Evaluasi Kinerja Pelayanan Dinas Perhubungan Dalam Bidang Transportasi Umum Perkotaan. Volume 13, No. 2, Tahun 2019, Hal. 53-61 
peraturan perundang-undangan dikaitkan dengan kondisi sosial ekonomi masyarakat agar peraturan perundang-undangan yang dibuat dapat terlaksana.Pemilik Angkutan kota dianjurkan dapat bekerjasama dengan baik dengan pihak Dinas Perhubungan Kabupaten Banjarnegara terkait pelaksanaan perpanjangan izin trayek.

\section{DAFTAR PUSTAKA}

Abdurahman, A, (2011). Aspek-aspek Pengawasan di Indonesia. Sinar Grafika, Jakarta

Fachruddin, I, (2013). Pengawasan Peradilan Administrasi Terhadap Tindakan Pemerintah. PT Alumni, Bandung

Kartini, Rahayu,(2007). Hukum Pengangkutan, UPT Penerbitan Universitas Muhammadiyah, Malang

Ningrum Wahyu Sofi,(2019). Jurnal Respon Publik Evaluasi Kinerja Pelayanan Dinas Perhubungan Dalam Bidang Transportasi Umum Perkotaan. Volume 13, No. 2, Malang.

Pudyatmoko, Y. Sri, (2009). Perizinan Problem dan Upaya Pembenahan, Grasindo, Jakarta,

Ratna, S. (2016).Cendekia Jurnal Ilmu Administrasi Negara Volume IX No. 1 Januari - Juni 2016

Tjakranegara, Soegijatna, (2016). Hukum Pengangkutan Barang dan Penumpang. Rineka, Jakarta,

Sudrajat, M. R., \& Isril, I. Pengawasan Dinas Perhubungan Komunikasi dan Informatika (Dishubkominfo) Kota Pekanbaru terhadap Fungsi Terminal Angkutan Umum Terminal Bandar Raya Payung Sekaki Kota Pekanbaru Tahun 2016 (Doctoral dissertation, Riau University

Sutedi, Adrian, (2010) Hukum perizinan dalam sektor pelayanan publik. Sinar Grafika, Jakarta. Undang-undang Nomor 22 Tahun 2009 tentang Lalu Lintas dan Angkutan Jalan Peraturan Daerah Provinsi Jawa Tengah No 8 Tahun 2013 Tentang Penyelenggaraan Perhubungan Di Provinsi Jawa Tengah

Peraturan Daerah Kabupaten Banjarnegara No 6 Tahun 2011 Tentang Retribusi Daerah

Peraturan Bupati Banjarnegara No 74 Tahun 2016 Tentang Kedudukan, Susunan Organisasi, Tugas Dan Fungsi Serta Tata Kerja Dinas Perhubungan Kabupaten Banjarnegara. 